\title{
Many a slip ......
}

Prof. Dr. Hemang Dixit

Medical Education Department, Kathmandu Medical College Teaching Hospital, Kathmandu, Nepal.

\author{
Tepal has been credited with two attributes in the \\ 1 past:
}

1. Good at making plans but poor in implementation.

2. Ability to get things done in the last minute.

Whilst a lot of credit has been given for Nepal's performance in the Millennium Development Goals (MDG), what must be remembered is that there are other aspects of Nepal's health care services which are not so shining examples.

One recent example is an occurrence which has been lying stagnant around for almost three decades. Apparently the Government of Nepal (GoN) had made a decision to build a Regional Hospital at Gwalasain of Dipayal-Silgadi Municipality in 1986. The government had then acquired 110 ropanis of land at the rate of Rs. 10,000 per ropani. After building a fence around the property at a cost of Rupees 5.5 million, the land has been left as it is. No compensation has been given nor any development done so far. The locals have now requested that the land be either utilized or alternatively be given back to the original owners. This is an example of functioning of the health ministry!

There have been a large number of grumblings about the state of affairs in the health settings of Nepal. True, there was:

1. Nepal's National Health Policy of 1991

2. Nepal's Health Sector Program- Implementation Plan, 2004-2009

3. Second Long-term Health Plan 1997-2017

4. Nepal's Second National Health Policy of 2013

The Three Year Interim Plan (2007/8 - 2009/10), had an objective of providing healthy environmental standards and hygiene in the municipal areas of the country. But it has not succeeded.

Following the Jana Andolan II it was accepted that Health Rights will be a Basic Right of the people. The Interim Constitution states that Basic Health Right is a fundamental right of every Nepali. After the first republic budget of $19^{\text {th }}$ September 2008 , the GoN decided to make health services up to 25 bedded district hospitals free, especially to the targeted population'. The government also decided that some 40 medicinal drugs at the District Hospital, 35 at the Primary Health Centres (PHCs) and 25 at sub-health posts will be free of cost. The National Urban Health Policy, introduced in July 2010, also had the objective of providing free primary health services to the poor people in the then existing 58 municipalities in the country.

What has to be realized is that whilst there was a lot of ballyhoo regarding these facilities, most of the medicines sent to these places, especially the distant ones had a very short time period before they became out of date or expired. It was literally a method for some people to dump old stock at competitive prices and make a profit. A lot of political mileage was made of the fact that free services was being provided to the people in the rural areas. What was not made clear was that this was a slip between the cup and the lip in the process of implementation. Another recent information as a result of the activities of the Commission for the Investigation of Abuse of Authority (CIAA) is that all is not well in the Ministry of Health and Population (MoHP) both in procurement and dispersal.

A new development is the result of Private Public Mix, a harbinger of proper functioning in the future. There are no less than 17 medical colleges and 11 dental colleges conducting both undergraduate and post graduate studies in Nepal. There is also a Nepal Academy of Medical Sciences (NAMS) involved in post graduate medical studies. Besides these there is the likelihood that two new medical colleges will be allowed by Kathmandu University (KU) in 2014 and some under Tribhuvan University (TU) will surely follow suit. The GoN is developing another university and another medical college as a public/private mix in the Far Western Region of the country. Likelihood is that the existing deemed universities run by the government will also be allowed to give affiliation to medical colleges. A further possibility of a Co-operative University under political patronage also exists and this institution is in the process of starting a medical college in Kathmandu too. 
What has and will this influx of activities do to the health of the Nation? The various medical colleges, situated in different parts of the country have certainly brought about a dispersal of health services all over our land. True, this dispersal has not reached the rural and far flung areas where the real deficiency of health services exist. Whilst there is no doubt that the basic health indicators are much better now than they were ten years ago, the fact is that this has been partly due to the contribution of these various medical colleges. Another fact is that the larger number of doctors in the community has resulted in more facilities in the urban sectors where, as much as $17 \%$ of the Nepali population now lives. However up to 2014 there were 58 Nagarpalikas or municipalities but the figure is due to be increased with an additional 41 more municipalities or further urbanization on the cards.

What is happening is that more private facilities in the nature of Private Hospitals, Nursing Homes and private clinics are increasing day by day. What is definitely true is that the services at these urban centres vary. Some of the charges are said to be exorbitant to the extent that patients get a very raw deal. There is also talk of 'fee splitting'. On top of all this there is the charge that taxis and even ambulance drivers are encouraged and compensated to bring patients. Thus some mutterings about the unfairness and unprofessional ethics are being voiced. It is because of this perhaps that a certain amount of 'self care' is prevalent in the suburban and rural areas. Whilst this is understandable in terms of costly health services, it has led to indiscriminate use of antibiotics and other drugs by both sellers and users of these items. It has also led to addiction to various items such as narcotics, speed drugs and even cough syrups. The GoN in the meantime states that the 'Operation, \& Upgradation Standards of Health Institutions - 2070' will provide accessible and quality health care services to the public in the coming year!

Who then is to see to all this? The Nepal Medical Council which is a legal semi-government body whose main function is to protect the health of the public should have the major role. Whether it has been doing its duty or not is another matter. An editorial in the last issue of Journal of Kathmandu Medical College (JKMC) drew

\section{REFERENCES}

1. Dixit H. Nepal's Quest for Health. 4th ed. Kathmandu: Educational Publishing House; 2014.

2. Adhikari RK. Nepal Medical Council and continuous professional development. J Kathmandu Med Coll. 2014;3(1):1-3. attention to the fact that the Nepal Medical Council Act assigns to NMC the role for protecting the health of the people by ensuring efficient and ethical medical practice by doctor's registration and further functioning under the Nepal Medical Council Act ${ }^{2,3}$.

To try to reduce the incidence of maternal and infant mortality, the GoN has been encouraging free delivery at health institutions with aid from external donors. This has met with some success and has to be increased all over the country. Another problem of women, namely prolapsed uterus, whilst being tackled by both the government and NGOs or INGOs has both praisers and detractors regarding its functioning. An area where the GoN has paid lip service to, is the services provided to older sections of our society. Whilst the nominal old age pension is a start, the fact is that its distribution needs to be regularized. Free geriatric facilities, or hospices are something that is urgently required and though promised is one of the facilities that may not reach the lips of the Nepali elders.

Though there have been a lot of discussions, the fact is that only about five percent of our National budget is spent on health. The demand is that it should be at least $10 \%$. True that the major contributors to developing our health services are external donors but another fact to remember is that for many years we have been unable to utilise the funds that they committed to us. Some of what has been utilised is the sending of equipment (X-ray, USG) to places in the rural areas where there are neither facilities nor personnel to use them. It is all for show or make believe that the fund has been used up and the donors mollified.

The GoN has announced a pilot scheme in five districts of Nepal where people will be encouraged to take out health insurance. Those who can pay for it will be encouraged to do so whilst for those who can't afford it, the government will pick up the tab. Whether this will work or not has yet to be seen. Will this be another slip up?

What is being stated by both experts and consumers of the health services in Nepal is that it is in a sorry state of affairs. Who will set it right?

3. Government of Nepal. Nepal Medical Council rules and regulations - $3^{\text {rd }}$ Amendment. Kathmandu: Government of Nepal; 2000. 